International Journal of Social Sciences and Humanities
Available online at http://sciencescholar.us/journal/index.php/ijssh
Vol. 2 No. 1, April 2018, pages: $10 \sim 23$
e-ISSN: 2550-7001, p-ISSN: $2550-701 \mathrm{X}$
http://dx.doi.org/10.29332/ijssh.v2n1.72

\title{
MSMEs Credit Distribution and Non-Performing Loan towards Banking Companies Profit in Indonesia
}

\begin{abstract}
CrossMark
Ketut Tanti Kustina a , I Gusti Ayu Agung Omika Dewi b , Gine Das Prena c , I Gusti Ayu Diah Utari d,

Article history: Received 17 August 2017, Accepted in revised form 20 January 2018, Approved 2 February 2018, Available online 5 February 2018

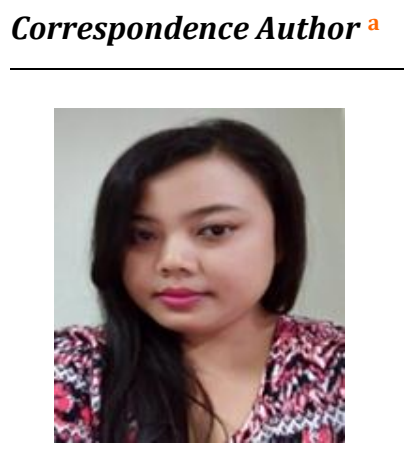

Keywords

Banking companies; Companies profit; MSMEs credit; Non-performing loan; Profit;

Abstract

The problems raised in the present research was related to the effect of MSMEs credit distribution loan and Non-Performing Loan (NPL) credit towards the banking companies profit in Indonesia. The study was intended to examine and obtain empirical evidence on the effect included (1) MSMEs credit variable to NPL variable. (2) MSMEs credit variable distributed to profit variable. (3) NPL to the profit variable and (4) to determine the effect indirectly MSMEs credit variable to profit variable through NPL in banking companies which included the 15 largest credit banks of MSMEs in Indonesia. The study used secondary data sources and data types used as a quantitative data. It was collected through documentation studies. The data analysis technique was applied Path Analysis on the software (SPSS). The hypothesis result testing was obtained that (1) the total amount of MSMEs credit had a significant positive effect on the banking company profit. (2) MSMEs credit positively significant to NPL of the banking company. (3) NPL had a significant negative effect on the company profit. (4) MSMEs credit could directly effect to profit and also indirectly affect the MSMEs credit could effect NPL as an intermediary variable then to variable profit. The direct coefficient value $(0,301)$ was lower than indirect coefficient $(0,404)$. Therefore, it can be concluded that there was an indirect effect of MSMEs credit channeled to NPL as an intermediate variable then to profit variable. The expected contribution could be obtained from the results was to assist the management in the banking sector in credit management included micro, small and medium enterprises (MSMEs) as well as become a consideration for stakeholders of the banking sector in decision making.
\end{abstract}

e-ISSN : 2550-7001, p-ISSN : 2550-701X ${ }^{\circ}$ Copyright 2018. The Author. SS Journals Published by Universidad Técnica de Manabí.

This is an open-access article under the CC BY-SA 4.0 license

(https://creativecommons.org/licenses/by-sa/4.0/) All rights reserved.

a University of National Education (Undiknas) Denpasar (tantikustina@undiknas.ac.id)

b University of National Education (Undiknas) Denpasar (omikadewi@undiknas.ac.id)

c University of National Education (Undiknas) Denpasar (ginedasfrena@undiknas.ac.id)

d University of National Education (Undiknas) Denpasar (diahutari@undiknas.ac.id) 


\section{Contents}

Abstract

1. Introduction .

2. Research Method

3. Results and Analysis

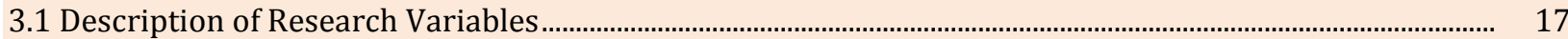

3.2 Path Analysis

4. Conclusion

Acknowledgements

\section{Introduction}

The existence of Micro, Small, Medium Enterprises (MSMEs) in Indonesia which is now a major supporter of the national economy is considered worthy greater attention. MSMEs has an important role in economic growth in Indonesia. It is evident when the economic crisis in Indonesia occurred in 1998, the sector of MSMEs can survive the economic crisis wherein a long time companies collapsed due to the crisis that occurred. The other than it, the contribution is given by MSMEs to the Gross Domestic Product of the State of Indonesia can be stated high, unlike in 2016 was $60.34 \%$ and helping absorption of workers in the sector of MSMEs was $97.22 \%$ in the last period (CNN Indonesia, 2016).

The Indonesia Government seeks to empower MSMEs by issuing various policy packages aimed at improving the real sector and, to expand employment opportunities, accelerate the development of the real sector and reducing poverty in Indonesia. The government realizes the government's effort to empower MSMEs in Indonesia through the issuance for Presidential Instruction (INPRES) No. 6 in 2007 on the Policy of Acceleration of Real Sector Development and Empowerment of Micro, Small and Medium Enterprises. The implementation spearhead of the impress issuance with the credit launch for the MSMEs actors and cooperatives with the loan pattern or also known as People Business Credit (KUR).

KUR is a government effort to empower MSMEs and Cooperatives to expand employment opportunities, accelerate the development of the real sector and to reduce poverty in Indonesia. The KUR launching has been conducted since November $5^{\text {th }}, 2007$ by the President of the Republic of Indonesia through 33 intermediary banks in a successful manner. From the beginning of KUR launch in 2007 until 2014, for seven years only total funds by the government amounted to IDR. 16.7 trillion, has succeeded in mobilizing bank funds amounting to IDR. 178.85 trillion to be channeled to MSMEs with NPL average about $3.3 \%$. The success indicator is KUR program has managed to absorb labor about 20,344,639 workers. Even KUR distribution funds were temporarily suspended in its seventh year its implementation in mid-2014 as it exceeded the target set by the government.

Credit distribution for MSMEs is not limited to banks designated as implementing banks of KUR suppliers. Based on Bank Indonesia Regulation (PBI) No. 17/12/PBI/2015 on granting credit or financing by commercial banks and technical assistance in the context of MSMEs development, banks are required to distribute 20\% MSMEs loans from total loans gradually until 2018. Banking credit channeling arrangements to MSMEs segments by Bank Indonesia (BI) which are then forwarded by the Financial Services Authority (OJK) in 2012 have been set. The banking credit has been gradually conducted with a portion of at least $5 \%$ for MSMEs segment in 2015. The portion of at least $10 \%$ to MSMEs segment in 2016, the share of at least 15\% to MSMEs segment in 2017 and starting in 2018 banks should provide a portion of at least $20 \%$ to MSMES segment. The sanctions for banks that do not distribute the portion of MSMEs bank credit that has been determined is the bank exposed disidentify reduction of demand deposit services. Banks can not meet the minimum requirements for MSMEs credit are also not entitled to incentives to loosen the upper limit of the Loan to Funding Ratio (LFR) ratio to $94 \%$ from $92 \%$.

MSMEs credit each year loans have a good improvement, in general, the improvement is pursuing the growth of total banking credit. Based on data from the Info Bank Research Bureau (2016), MSMEs credit grew approximately $7,63 \%$ in 2016 , which was slightly lower than the total growth of banking loans only

Kustina, K., Dewi, I., Prena, G., \& Utari, I. (2018). MSMEs Credit Distribution and Non-Performing Loan towards Banking Companies Profit in Indonesia. International Journal Of Social Sciences And Humanities (IJSSH), 
7.87\%. However, in accordance with the growth in MSMEs lending, the rising risk of non-performing loans or is known as NPL. The greater the total amount of the credit, the greater of increasing risk NPLs number.

Kiryanto (2015) stated that the increase of NPL ratio of MSMEs as well as due to the economic slowdown, also caused some MSMEs debtors to meet their obligations to the banks due to their business is disrupted by the drop in turnover, especially, export-oriented MSMEs. Some MSMEs engaged in the plantation sector, construction, retail trade, and mining experience pressure due to the global economic conditions impact in Indonesia. If the global and national economic conditions improve, MSMEs, NPL will decline. The Bank should be able to minimize NPL. It will have an impact on the profitability of the credit interest income (Utami and Putra, 2016). The incidence of NPL will result in the bank's losses due to the funds by the bank in the form of credit are not returned, or interest income is unacceptable and will ultimately affect the profit gain. The high NPL can affect the bank's policy in disbursing its credit, i.e., the bank is more cautious in crediting. Due to banks that give credit when NPL is high means that the bank is included risk taken (Pratiwi, 2012).

In the implementation of MSMEs, Credit distribution is to avoid the increase of NPL; the government has issued Regulation of the Coordinating Minister for Economic Affairs No. 8 in 2015 on Guidelines for the Implementation of KUR. It is mentioned in Article 32 of the Finance Policy Committee in MSMEs based on OJK statement stop KUR distribution for MSMEs. If the credit mastering NPL above 5\% in the six months. Financing Policy Committee at MSMES can give credit approval of MSMEs credit in the form of KUR if the credit bank has NPL below 5\% for three months consecutive.

According to Kasmir (2005), the role of banking as a financial institution is inseparable from credit problems, from bank activities as a financial institution, lending as its main activity. The total amount of the credit will determine the amount of the bank profits. The statement was reinforced by Wulandari (2009) that stated in her research results; the microcredit distribution effects bank operating profit. Similarly, in the credit distribution of MSMEs by banks, as the rules of the credit disbursement set by the government, the greater loans amount by banks for MSMEs is expected to increase the profits to be obtained.

\section{Research Questions}

Based on the above description, some problems are formulated as follow:

1. What the MSMEs credit significantly affecting the banking companies profit that is included the 15 largest MSMEs credit banks in Indonesia?

2. What the MSMEs credit significantly affecting NPL banking companies that is included the 15 largest MSMEs credit channeling banks in Indonesia?

3. What the NPL significantly affect the banking companies profit that is included the 15 largest MSMEs credit banks in Indonesia?

4. What the MSMEs credit affecting profit indirectly through NPL in banking companies that is included the 15 largest MSMEs credit banks in Indonesia

\section{Research Aims}

The purpose of the present research are:

1. To find out the effect of MSMEs credit to the banking companies profit that is included the 15 largest MSMEs credit banks in Indonesia?

2. To find out the effect of MSMEs credit to NPL banking companies that is included the 15 largest MSMEs credit banks in Indonesia?

3. To know the effect of NPL on the banking companies profit that is included the 15 largest MSMEs credit banks in Indonesia?

4. To know the effect of MSMEs credit that is channeled to profit indirectly through NPL in banking companies that is included the 15 largest MSMEs credit banks in Indonesia

\section{Theoretical Framework \\ Signaling Theory}

According to Hartono (2005), signaling theory stated that a good quality company would deliberately signal to the market. Thus the market is expected to differentiate good and bad quality companies. The 
signal theory is based on the assumption that the information received each and party is not the same. In other words, signaling theory is concerned with information asymmetry. Signaling theory indicates the existence of the information asymmetry between the management company and parties concerned with the information. Therefore, the managers need to provide information to interested parties through the issuance of financial statements. Signaling theory suggests how a company should signal the users of the financial statements. This signal is information about what has been done by the management to realize the desire of the owner. The information received by the investor first interpreted as a good signal (good news) or bad signal (bad news). If the profit statement by the firm increases, then the information can be categorized as a good signal, as it indicates good company condition. Conversely, if the reported profit decreases, then the company is not in good condition that is considered a bad signal. In term of this, the bank seeks to increase its profit through credit channeling and keep NPL below 5\%. Therefore, the information from the bank is categorized as a good signal.

\section{Bank Definition}

According to Kasmir (2007), the bank is a financial institution whose main activity is collecting funds from the society and channeling the funds back to the society and providing other bank services. Whereas, according to IAI in PSAK No. 31, Bank serves as a financial intermediary between the party who owns the funds and the party who needs the funds, as well as the functioning institution to pass the payment. It can be concluded that bank is a financial institution whose activities collect funds from the public in the demand deposits form, savings, and deposits, then channel funds to the society in the loans form (credit). Providing other services that include deposit services, payment services, transfer, clearing, forex, safe deposit box, travelers check, credit card.

The main functions and aims for bank establishment in Indonesia are as Agent Of Development (especially for state-owned banks) and Financial Intermediary. The function establishing a bank as follows: (1) Agent Of Development: To maintain monetary stability in Indonesia. This function can be seen in two crediting credit programs, namely KIK (Small Investment Credit) and KMKP (Permanent Working Capital Credit). (2) Financial Intermediary: The Bank serves as an intermediary for the collection and funds distribution.

In accordance with its function, the benefits derived from banking services are as follows: (1) Working Balance; to support daily transaction procedures for business, thus to facilitate the process of receipt and payment of the transaction. (2) The investment fund as an investment place from idle, to get interested. (3) Saving purpose; to secure the money deposit, both physically (theft) and morally (inflation, devaluation, and depreciation).

\section{MSMEs Credits}

In the Law of the Republic of Indonesia No. 20 in 2008 on Micro, Small, and Medium Enterprises, Article 1 explained that MSMEs credit definition is the funds provided by the Government. Regional Government, Business World, and the society through banks, cooperatives, and non-bank financial institutions, to develop and strengthen the capital of Micro, Small and Medium Enterprises. Meanwhile, according to Calvary (2008) stated that Micro, Small, and Medium Business Loan is a lending and borrowing activity between individuals or business entities or certain legal entities at the level of micro, small and medium enterprises, capable of performing legal acts with the trust principal.

If we follow the development of the bank's loss/profit sheet in Indonesia, the main income from the operational results is mainly still dependent on the income of the credit interest (Kustina and Dewi, 2016). The banks seek to increase their profits through the credit channeling than the loan disbursement, which is expected to increase the operating profit earned by the bank. The loan disbursement generates operating income in the form included interest income, provision, commission, other than that the credit distribution also has a risk of NPL that is a burden component for the bank, due to the bank will not get an interest income, and a number of the loan principal has.

\section{Nonperforming Financing/ Non-Performing Loan (NPL)}

According to Darmawi (2012), the credit provision contains various risks caused by the possibility or not repaid by the debtor at the end of the loan (payment due date). The customer can not repay many Kustina, K., Dewi, I., Prena, G., \& Utari, I. (2018). MSMEs Credit Distribution and Non-Performing Loan towards Banking Companies Profit in Indonesia. International Journal Of Social Sciences And Humanities (IJSSH), 
things that cause the credit in time. No credit-free decision. No bank tone is capable of developing its business if the bank always avoids the risk. But not all risks are acceptable. Acceptable risk is a measurable risk. Thus, in determining whether to provide a loan or not, a banker should be able to estimate or measure the risk of being bad loans. According to Manurung and Rahardja (2004) regarding loan problems are: "If the good management, it will generate benefits for the bank, vice versa. If the management is not optimal and not careful, then that will encourage the NPL emergence. Credit is stated to be nonperforming financing. If the return is late than the planned schedule, not even returned at all."

Understanding Non-Performing Financing according to Dendawijaya (2003): "Non-performing loans are credits whose loan principal repayment and interest payments have been postponed for more than one year from payment due date based on the agreed schedule. According to Tamin (2012), the credit facility that runs in BI assessment. The group is divided into 5 groups namely Group $1=$ current/without arrears (L), Group 2 = Special Attention (DPK), i.e., 1 month delay, Group 3 = substandard (KL) or arrears of more than 1 to 3 months, Group 4 = Doubtful (D) or delinquent more than 3 to 6 months, Group $5=$ loss (overdue 6 months). Group 3-5 is called NPL.

According to Bank Indonesia Circular Letter No.8/30/DPBPR/2006, NPL is a comparison between the loans given (quality of KL, D, and M) after deducting Allowance for Earning Assets Losses (PPAP) with the total amount of the loans granted. According to Siamat (2005), NPL or often called non-performing financing can be interpreted as a loan that has difficulty repayment due to intentional factors and or due to external factors beyond the control ability of the debtor. According to Riyadi (2006), the NPL amount allowed by Bank Indonesia is $5 \%$ at most. If it exceeds 5\%, it will affect the rating of Bank Health, that will reduce the value/score obtained.

The arrears credit cause the bank's ability to disburse loans to be affected due to reducing funds that will be for credit. The bank must establish an allowance for provision of credit receivables or Provision for Earning Assets Loss (PPAP) to prevent the risk of loss. Thus, there is a negative relationship between NPL and the amount of MSMEs credit (Soedarto, 2004). According to Mahsud (2004), NPL is a ratio used to measure the bank's ability to cover the failure risk of the credit repayment by the debtor. NPL reflects a credit risk, the higher NPL level, the greater of the credit risk borne by the bank. With the high NPL rate, banks should provide greater reserves, thereby reducing bank capital. The amount of capital greatly affects the extent of the credit expansion. The NPL magnitude is one of the reasons for the bank's difficulty in lending.

\section{Hypotheses}

a. Effect of MSMEs credit to profit

Budiwati and Jariah (2012) stated that the better bank's ability to distribute credit, the more interest income received by the bank from the loan. Therefore, the bank's ability in obtaining and increasing profits is increasing. The research was conducted by Hidayat (2012), showed that the amount of the credit affects the profit measured by Net Profit Margin. The statement is supported by Bedrock and Suarez (2000) in Utami and Putra (2016) that stated the amount of credit in distributed effect on earnings. Based on the description can be formulated hypothesis as follows:

H1: MSMEs credit significantly positively affects the banking companies profit that is included the 15 largest MSMEs credit banks in Indonesia?

b. The effect of MSMEs credit amount to Non-Performing Loan (NPL)

Along with the MSMEs credit growth, accompanied by the rising risk of NPL. The greater the number of loans by the banks, the risks of increasing NPL or higher NPL. The credit risk is a disappearance risk of the bank funds to the public, either in part or whole by existing credit agreements (Sudirman, 2013). The higher credit amount is by the banking society, the credit risks faced by the banks will be higher, the risk may be in NPL form or non-current payments, or in banking terms known as Non-Performing Loan (Cendana and Ramantha, 2017). Therefore, it can be stated that the amount of credit can affect the NPL. Based on the description then it can be formulated hypothesis as follows:

H2: The MSMEs credit significantly positively NPL affects of the banking companies profit that is included the 15 largest MSMEs credit banks in Indonesia? 
c. Effect of Non-Performing Loan (NPL) on profit

The NPL incidence will result in the bank's losses due to the funds by the bank in the credit form are not returned, or interest income is unacceptable and will ultimately affect the profits earnings. Dendawijaya (2005) stated that with NPL, banks would lose the opportunity to earn income from loans, thereby reducing their earnings. It is supported by Gelos (2006) statement in Buyung (2009), and Sari et al. (2012) stated that NPL has a significant negative effect on bank performance as measured by Return On Assets (ROA). Based on the description then it can be formulated hypothesis as follows:

H3: NPL has a significant negative effect on the banking companies profit that is included the 15 largest MSMEs credit banks in Indonesia?

d. Effect of MSMEs credit to profit indirectly through Non-Performing Loan (NPL)

The credit granting by risk banking firms. The more credit distributed by banks to the society, the greater credit risk that will be faced by the bank. The risks can be NPL emergence which in banking terms is known as the Non-Performing Loan (NPL) ratio. NPL may result in the bank to affect the profit gain, due to the funds in the credit form by the bank does not return as capital, and the bank does not get credit interest income. It indicates that the greater NPL ratio will make financial institutions slowly reduce the credit distribution to the society and will affect the earnings its profits. It is in accordance with the research results by Wangi and Ramantha (2017) stated that the greater NPL ratio would make financial institutions slowly reduce the credit distribution to the society and will indirectly reducing profit. Based on the description, it can be formulated hypothesis as follows:

H4: MSMEs credit affects indirectly through Non-Performing Loan (NPL) in the banking companies that is included the 15 largest MSMEs credit banks in Indonesia

\section{Conceptual Framework}

Kasmir (2005) stated that the banking role as a financial institution is inseparable from credit problems, even bank activities as a financial institution, credit is the main activity. Kasmir (2005) stated that the banking role as a financial institution can not be separated from credit problems, as a financial institution, lending is the main activity. When NPL is high, the banking companies will face financial difficulties. Therefore, the fund's amount that can be used to disburse on credit is reduced. The low NPL shows that the bank's customers have a good ability to pay the debt. Thus, the bank again has some funds that can be used to disburse in the form of credit to other customers (Isnurhadi et al., 2015). However, the high NPL is one of the reasons for the bank's difficulty in lending. The credit amount is, and NPL has interrelated relationships. The greater credit amount is greater NPL likelihood, i.e., when credit quality enters Group 3 = Substandard (KL) or arrears of more than 1 to 3 months, Group $4=$ Doubtful (D) or overdue 3 to 6 months, Group 5 = loss (overdue six months). After the NPL period entered in Substandard criteria (KL), i.e., delinquent more than three months, then NPL occurs will affect the loan amount is by the banks. The better bank's ability to distribute the credit, the more interest income will be received by the bank from the credit channeled. Therefore, the bank's ability to obtain and increase profits will increase. NPL occurrence will result in losses of the bank due to the funds are by the bank in the form of credit are not returned, or interest income is unacceptable and will ultimately affect the profit gain. The conceptual framework in the present study can be illustrated in Figure 1 below:

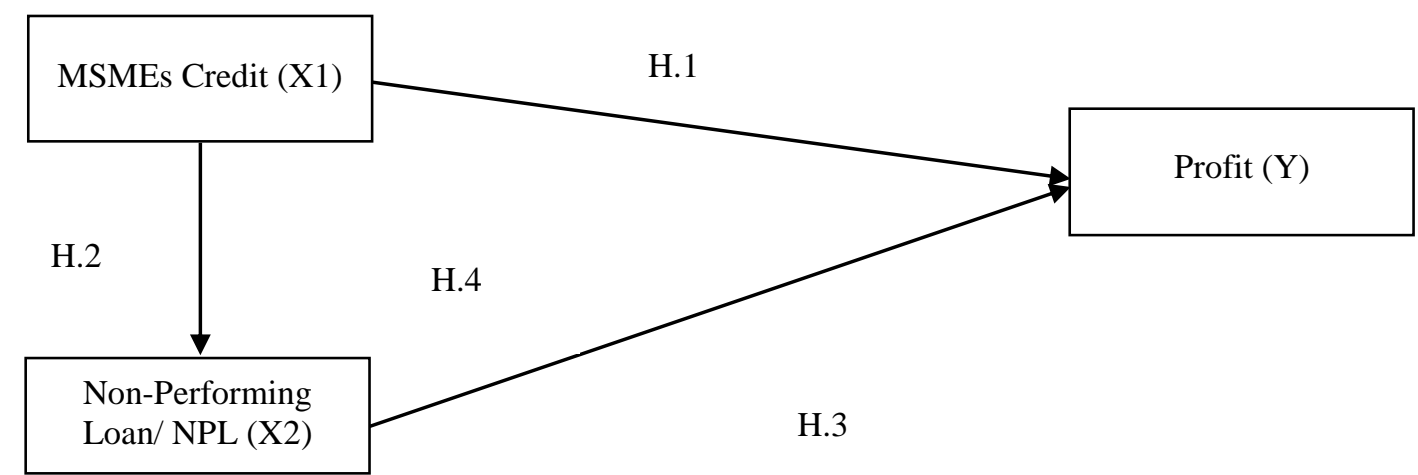

Figure 1. Research Concept Framework

Kustina, K., Dewi, I., Prena, G., \& Utari, I. (2018). MSMEs Credit Distribution and Non-Performing Loan towards Banking Companies Profit in Indonesia. International Journal Of Social Sciences And Humanities (IJSSH), 2(1), 10-23. doi:10.29332/ijssh.v2n1.72 


\section{Research Variables}

a) Exogenous Variable

The independent exogenous variable in the study is the total amount variable of MSMEs credits. MSMEs credits amount is funding by banks to develop and strengthen the MSMEs credit in the banking companies that include 15 largest credit banks of MSMEs in Indonesia.

b) Endogenous Variable

1. Non-Performing Loan (NPL)

Non-Performing Loan (NPL) variable in the research is endogenous variables and as an intermediate variable. NPL is the total amount of non-performing financing, wherein the debtor can not fulfill the MSMEs credit payment installment. When the credit quality goes into the substandard quality (KL), i.e., overdue for more than 1 to 3 months, doubtful credit quality (D) from 3 to 6 months, quality loss (M) is in arrears. For more than six months in the banking companies that is included the 15 largest MSMEs credit banks in Indonesia

2. Profit

In the present study, profit is endogenous dependent variable. The profit is referred a net income. It is the positive difference on income minus the costs and taxes on the banking companies that is included the 15 largest MSMEs credit banks in Indonesia

\section{Research Method}

\section{Research Location}

The research location is in the banking companies in Indonesia and distributes MSMEs credit.

\section{Population and Research Sample}

The population used in this research is banking companies in Indonesia that distribute credit Micro, Small and Medium Enterprises (MSMEs). The method of collecting the data sampling is used a purposive sampling method. The population that used as research sample is the population that meets the criteria of a particular sample. The criteria are as follows:

a) Banking company that provides MSMEs credits

b) Banks categorized into the top 15 largest MSMEs credit distributors in 2015-2016

c) The company has issued its annual statement from 2015 to 2016

d) Displaying data and information related to NPL

e) The annual financial report for December, 31 dated.

Based on the results of sample selection is obtained 15 (fifteen) banking companies or total observation 30 companies. The following are a list of the companies are used as samples:

a) Bank Rakyat Indonesia (Bank BRI)

b) Bank Mandiri

c) Bank Negara Indonesia (Bank BNI)

d) Bank Central Asia (Bank BCA)

e) Panin Bank

f) Bank Danamon

g) Bank Maybank Indonesia

h) Bank CIMB Niaga

i) Bank Bukopin

j) Bank Nagari

k) Bank Syariah Mandiri

l) Bank UOB Indonesia

m) Bank Tabungan Negara (Bank BTN)

n) Bank Tabungan Pensiunan Nasional (Bank BTPN)

o) Bank OCBC NISP 
Types and Data Sources

The data used is a secondary data. Data were obtained from various sources included OJK website (www.ojk.go.id), info bank magazine and Indonesian Capital Market Directory (ICMD). The types of data are used a quantitative data in the form of the total amount of profits, and MSMEs credit money, NPL for the 15 largest MSMEs credit banks in Indonesia.

\section{Data Analysis}

The data were analyzed through a descriptive statistics, then conducted a hypothesis test. The descriptive statistics provide an overview of the frequency distribution of the research variables, maximum values, minimum, mean, and standard deviations. The data analysis using path analysis technique.

\section{Path Analysis}

The path analysis is used to direct and indirect test effects through an intermediate variable. In the present research, it is used path analysis through SPSS software. The path coefficient ( $\beta$ ) is a standardized regression coefficient. The path coefficient is calculated by making two structural equations, i.e., simple regression equation and multiple regression equations as follows;

$$
\begin{array}{ll}
\mathrm{X} 2 & =\beta_{2} \mathrm{X}_{1}+\mathrm{e}_{1} \\
\mathrm{Y} & =\beta_{1} \mathrm{X}_{1}+\beta_{2} \mathrm{X}_{2}+\mathrm{e}_{2}
\end{array}
$$

Description:

$\begin{array}{ll}\mathrm{Y} & =\text { Profit } \\ \beta 1-\beta 2 & =\text { Regression coefficient } \\ \mathrm{X} 1 & =\text { Total amount of MSMEs credit distributed } \\ \mathrm{X} 2 & =\text { Non Peforming Loan (NPL) } \\ \mathrm{e} & =\text { Error }\end{array}$

The indirect effect amount is calculated by multiplying the indirect coefficient. If the direct coefficient relationship is smaller than indirect coefficient, it can be concluded that there is indirect effect between variables.

\section{Results and Analysis}

\subsection{Description of Research Variables}

Descriptive statistics in the present study are presented in the table as follows:

Table 1

\begin{tabular}{llrrr}
\hline & \multicolumn{3}{c}{ Statistics } \\
\hline & \multicolumn{2}{l}{ Profit } & NPL & $\begin{array}{c}\text { Total amount of MSMEs } \\
\text { credit }\end{array}$ \\
\hline $\mathrm{N}$ & Valid & 30 & 30 & 30 \\
\cline { 2 - 5 } & Missing & 0 & 0 & 0 \\
\hline Mean & 8441547.67 & 1743931.63 & 28355509.50 \\
\hline Std. Deviation & 11883903.207 & 2071333.916 & 18583479.979 \\
\hline Minimum & 229088 & 6805228 & 10825014 \\
\hline Maximum & 40817815 & & & 80320394 \\
\hline
\end{tabular}

Source: Data processed, 2018

The descriptive statistics aims at providing information on the research variables characteristics, including minimum, maximum, mean, and standard deviation. Mean measurements are the most commonly used means of measuring the central value of the data distribution. Whereas, the standard deviation is the value difference of the data studied with the average value. Based on the above table it can be seen that the

Kustina, K., Dewi, I., Prena, G., \& Utari, I. (2018). MSMEs Credit Distribution and Non-Performing Loan towards Banking Companies Profit in Indonesia. International Journal Of Social Sciences And Humanities (IJSSH), 2(1), 10-23. doi:10.29332/ijssh.v2n1.72 
minimum value for MSMEs credit is distributed (X1) is 10825014 and its maximum value is 80320394 . The mean for the amount of MSMEs credit channeled (X1) is 28355509.50, with standard deviation is 18583479.979. For NPL variable (X2), the minimum value is 119593, and the maximum value is 6805228. Mean for NPL (X2) is 1743931.63, with default deviation is 0,44978 . For-profit variable (Y), the minimum value is 229088 , and the maximum value is 40817815 . The mean profit variable is 8441547.67 , with the standard deviation is 11883903.207.

\subsection{Path Analysis}

a) Effect of MSMEs credit to profit

The following is the result of path analysis using SPSS are presented in the table as follows:

Table 2

Analysis of the effect of MSMEs and NPL credits on profit

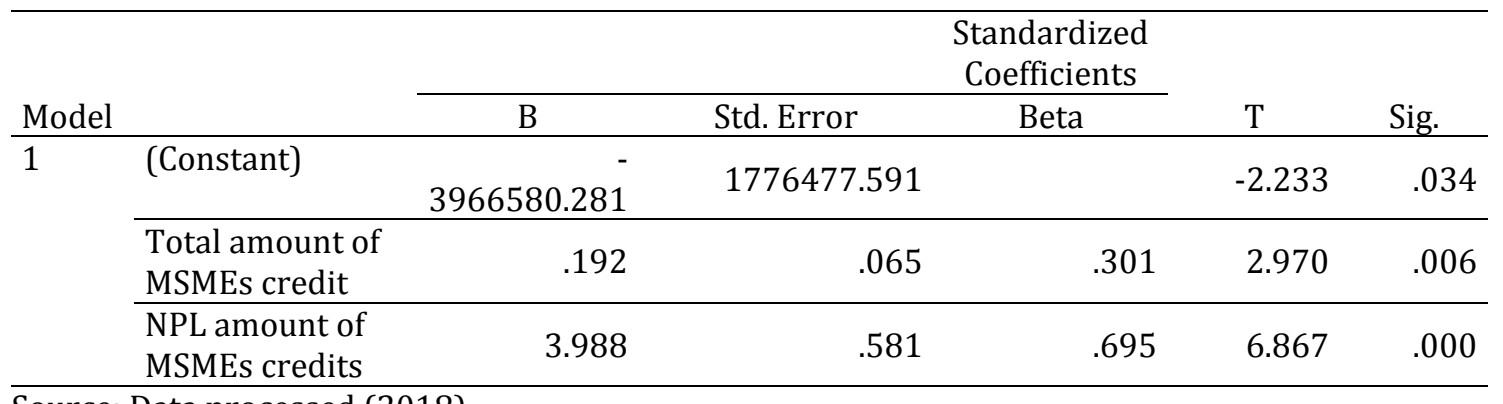

Source: Data processed (2018)

To see whether there is effect between the variable of credit amount discharged to earnings of the banking company that is included 15 biggest MSMEs credit bank in Indonesia hence conducted a comparison of $t$ result arithmetic with the level of significance is 0,05 . The first hypothesis test result (H1) Table 1 is obtained significance research value is 0.006 smaller than 0.05 then the first hypothesis (H1) accepted that means the MSMEs credit amount has a significant positive effect on the profit of the banking companies including 15 largest MSMEs credit banks in Indonesia. The greater bank's ability to disburse credit, the more interest income the bank receives from the loan. Therefore, the bank's ability at obtaining and increasing profits is increasing. With increasing NPL, the banking companies will lose the opportunity to earn revenues from loans, thus, affecting their profit.

b) Effect of MSMEs credit to Non-Performing Loan (NPL)

The following is the result of path analysis using SPSS to know the effect of MSMEs credit to NPL is presented in the table below:

Table 3

Analysis of the effect of MSMEs credit on NPL

\begin{tabular}{|c|c|c|c|c|c|c|}
\hline \multirow[b]{2}{*}{ Model } & & \multicolumn{2}{|c|}{ Unstandardized Coefficients } & \multirow{2}{*}{$\begin{array}{c}\begin{array}{c}\text { Standardized } \\
\text { Coefficients }\end{array} \\
\text { Beta }\end{array}$} & \multirow[b]{2}{*}{$\mathrm{t}$} & \multirow[b]{2}{*}{ Sig. } \\
\hline & & $\mathrm{B}$ & Std. Error & & & \\
\hline 1 & (Constant) & -96020.721 & 577721.498 & & -.166 & .869 \\
\hline & $\begin{array}{l}\text { MSMEs Credit } \\
\text { amount }\end{array}$ & .065 & .017 & .582 & 3.789 & .001 \\
\hline
\end{tabular}

To know, whether there is an effect between the credit amount variable to NPL of banking companies that are included the 15 largest MSMEs credit distribution in Indonesia, then is conducted comparing $t$ results arithmetic with a significance level is 0.05 . The the second hypothesis test result $(\mathrm{H} 2)$ is obtained the significant research value is 0.001 smaller than 0.05 , then 
the second hypothesis (H2) is accepted which means that MSMEs credit positively significant to NPL, the largest MSMEs credit in Indonesia. The banking companies disburse the higher credit amount, the credit risk faced by banks will be higher. The risk may be in the form of non-performing financing or non-current payments, or in banking terms known as Non-Performing Loan (NPL). Therefore, it can be concluded that the credit amount can affect to NPL.

c) Effect of Non-Performing Loan (NPL) on profit

To know the effect of NPL variable to profit of the banking companies that is included the 15 biggest MSMEs credit banks in Indonesia, then comparing the $t$ result arithmetic with significance level is 0,05 . The significance research value obtains the third hypothesis test result (H3) in Table 3 is 0.000 smaller than 0.05 , then the third hypothesis (H3) is accepted which means NPL significantly negatively affects the profit of the banking companies including the largest 15 banks MSMEs credit channel in Indonesia. The greater NPL will result in the loss of the bank due to the funds by the bank in the form of credit are not returned, or interest income is unacceptable and will ultimately affect the profits. The study results were by the research results by Dendawijaya (2005), Gelos (2006) in Buyung (2009) and Sari et al. (2012) stated that NPL affects the bank's profit.

d) Effect of MSMEs credit to profit indirectly through Non-Performing Loans (NPL)

The path analysis result shows that MSMEs credit can directly effect to profit and can also have an indirect effect that is MSMEs credit that channeled can effect NPL as an intermediate variable then to profit variable. The direct magnitude effect of MSMEs credit channeled to profit is 0.301 . The indirect magnitude effect is calculated by multiplying the indirect coefficient i.e., $(0.582) \times(0.695)=$ 0 , 404. Since the direct relation coefficient is (0.301) less than the indirect coefficient is 0.404). It can be concluded that there is an indirect effect of MSMEs credit channeled to NPL as an intermediate variable then to profit variable. It means that the greater credit amount by the banking hence the risk of loans problem or NPL higher and can affect the bank's profit from bank interest income. Hence, the fourth hypothesis (H4) in this research is acceptable, i.e., MSMEs credit affects profit indirectly through NPL in the banking companies which are among the 15 biggest MSMEs credit banks in Indonesia.

\section{Conclusion}

Based on the results of research on the effect of MSMEs credit, Non-Performing Loan (NPL) to profit in the 15 major banking companies, MSMEs channeling in Indonesia can be drawn some conclusion:

a) The first hypothesis test result (H1) is obtained the significant research value is 0.006 less than 0.05 , then the first hypothesis (H1) is accepted which means the UMKN credit amount has a significant positive effect on the banking companies profit that is included the 15 largest MSMEs credit banks in Indonesia.

b) The second hypothesis test result $(\mathrm{H} 2)$ is obtained the significant research value is 0.001 smaller than 0.05 , then the second hypothesis (H2) is accepted which means that MSMEs credit has a positive effect significantly to NPL, the largest MSMEs credit bank in Indonesia.

c) The third hypothesis test result (H3) is obtained the significant research value is 0.000 smaller than 0.05 , then the third hypothesis (H3) is accepted which means NPL significantly negatively affects the banking companies profit that is included the largest 15 MSMEs credit banks channeling in Indonesia.

d) The path analysis results show that MSMEs credit can directly affect to profit and can also have an indirect effect that MSMEs credit can affect NPL as an intermediary variable and then to the profit variable. The direct coefficient value is $(0,301)$ smaller than indirect coefficient $(0,404)$. Therefore, it can be concluded that there is an indirect effect of MSMEs credit channeled to NPL as an intermediate variable then to profit variable.

\section{Research Implication}

Theoretically, the study results are expected to provide a deeper illustration and understanding of the effect of MSMEs credit and NPL to the banking company's profit. It is as well as expected to be used as reference material for further research.

Kustina, K., Dewi, I., Prena, G., \& Utari, I. (2018). MSMEs Credit Distribution and Non-Performing Loan towards Banking Companies Profit in Indonesia. International Journal Of Social Sciences And Humanities (IJSSH), 2(1), 10-23. doi:10.29332/ijssh.v2n1.72 
Practically, for Banking that is studied, it is expected to provide information on the effect of MSMEs credit, NPL to the bank profit. Therefore, it can be used as the basis for decision making related to MSMEs, NPL, and profit in banking. As well as a material review for the bank, to increase MSMEs credit provided the bank itself. It is important for banks considering the regulation of the bank credit distribution to MSMEs segment by the Government through Bank Indonesia's (BI) central bank which is then forwarded by the Financial Services Authority (OJK) in 2012. It has been gradually conducted with a portion of at least $5 \%$ to the segment of MSMEs in 2015, at least 10\% to MSMEs segment in 2016, at least $15 \%$ to MSMEs segment in 2017 and starting in 2018, the banks should provide a portion of at least 20\% to MSMEs segment. There are sanctions for banks that do not distribute the portion of MSMEs credit that has been determined is the bank exposed disincentives reduction of the demand deposit services. The banks that can not meet the minimum requirements for MSMEs credit are also not entitled to incentives to loosen upper limit of Loan to Funding Ratio (LFR) ratio to 94\% from 92\%.

\section{Research Limitations}

This research has been conducted in accordance with scientific procedures, but has limitations included;

a) The independent variables studied in the study are still limited to the variable MSMEs credit distribution in KUR program, and NPL as well as the effect on profit as the dependent variable. Many other variables can also be studied the effect on profit in the banking companies in Indonesia that have not been researched and need to be conducted for further researchers.

b) There are the research samples selection conducted only on 15 banks in Indonesia the largest supplier of MSMEs credit in Indonesia as well as taken from 2016 and 2017 periods.

\section{Suggestions for Further Researcher}

For the next researcher is hoped to add another technique and tool analysis to know the effect on profit on the banking companies in Indonesia. In the subsequent research, the researcher can be on the whole banking company in different time periods.

\section{Acknowledgements}

My deep and sincere gratitude were presented to God for having granted me the ability and the opportunity to complete this paper. As well as, I have much appreciated to my friends for their support, suggestion, contribution in finishing this research. I would like thanks to I Wayan Suryasa that has given me good advisement. Last but not least, I dedicated my dreadful thank my friend who those as editor in SS who has reviewed and approved this study to be published. 


\section{References}

1. Ali, M., \& Supriyanto, E. B. (2004). Asset liability management: menyiasati risiko pasar dan risiko operasional dalam perbankan. Elex Media Komputindo.

View in (Google Scholar)

2. Brock, P. L., \& Suarez, L. R. (2000). Understanding the behavior of bank spreads in Latin America. Journal of development Economics, 63(1), 113-134.

View in (Google Scholar)

3. Budiwati, H., \& Jariah, A. (2012). Analisis Non Performing Assets Dan Loan to Deposits Ratio Serta Pengaruhnya Terhadap Net Interest Margin Sebagai Indikator Spread Based Pada Bank Umum Swasta Nasional Di Indonesia Periode 2004-2007. WIGA-Jurnal Penelitian Ilmu Ekonomi, 2(2).

View in (Google Scholar)

4. Dye, R. A., \& Sridhar, S. S. (1995). Industry-wide disclosure dynamics. Journal of accounting research, 157174.

View in (Google Scholar)

5. Bakri, A. M., Bimbingan, D., Dedi Kusmayadi, S. E., Si, M., \& Ak, C. A. Pengaruh Kredit Diberikan Dan Non Performing Loan Terhadap Return On Assets.

View in (Google Scholar)

6. Fama, E. F., \& Jensen, M. C. (1983). Separation of ownership and control. The journal of law and Economics, 26(2), 301-325.

View in (Google Scholar)

7. Hanafi, M. M., \& Halim, A. (2007). Analisis laporan keuangan. Yogyakarta: UPP STIM YKPN.

View in (Google Scholar)

8. BPFE, U. (2007). Metodologi Penelitian Bisnis: Salah Kaprah Dan Pengalaman-Pengalaman. View in ( Google Scholar).

View in (Google Scholar)

9. Herman, D. (2012). Manajemen Perbankan, cetakan kedua. Penerbit Bumi Aksara, Jakarta.

View in (Google Scholar)

10. Kasmir, B., \& Lainnya, L. K. (2014). Edisi Revisi. PT RajaGrafindo Persada, Jakarta.

View in (Google Scholar)

11. Gunawan, B. (2015). Pengumuman Hasil Audit Badan Pemeriksa Keuangan terhadap Bank Indonesia sebagai Upaya untuk Melakukan Transparansi dan Akuntabilitas Bank Indonesia (Suatu Tinjauan dari Sisi Audit). Jurnal Akuntansi dan Investasi, 1(2), 93-103.

View in (Google Scholar)

12. Kustina, K. T., \& Dewi, I. A. O. (2016). Pengaruh fee based income terhadap perubahan laba perusahaan perbankan di bursa efek indonesia (studi pada 10 bank dengan laba terbesar di indonesia). Prosiding, 149165.

View in (Google Scholar)

13. Manurung, M., \& Rahardja, P. (2004). Uang, perBankan, dan ekonomi moneter: kajian kontekstual Indonesia: Berdasarkan UU no. 7/1992 sebagaimana diubah dengan UU no. 10/1998, UU no. 3/2004 (Perubahan atas UU no. 23/1999): dilengkapi arsitektur perBankan Indonesia (API). Penerbitan Fakultas Ekonomi, Universitas Indonesia.

View in (Google Scholar)

Kustina, K., Dewi, I., Prena, G., \& Utari, I. (2018). MSMEs Credit Distribution and Non-Performing Loan towards Banking Companies Profit in Indonesia. International Journal Of Social Sciences And Humanities (IJSSH), 2(1), 10-23. doi:10.29332/ijssh.v2n1.72 
14. Kusaly, D. A., Tommy, P., \& Maramis, J. (2017). Pengaruh Kebijakan Pemberian Kredit Terhadap Non Performing Loan Dan Harga Saham Bank Di Bursa Efek Indonesia (BEI). Jurnal EMBA: Jurnal Riset Ekonomi, Manajemen, Bisnis dan Akuntansi, 5(2).

View in (Google Scholar)

15. Calvary, R. (2009). Ayo ke Bank Dapatkan Kredit UMKM. Jakarta: PT Elex Media Komputindo.

View in (Google Scholar)

16. Sari, T. M., Syam, D., \& Ulum, I. (2015). Pengaruh Non Performing Loan Sebagai Dampak Krisis Keuangan Global terhadap Profitabilitas Perusahaan Perbankan. Jurnal Akuntansi dan Investasi, 13(2), 83-98.

View in (Google Scholar)

17. Siamat, D., Kusumawardhani, P. N., \& Agustin, F. (2005). Manajemen lembaga keuangan: kebijakan moneter dan perbankan: dilengkapi UU no. 10 tahun 1998, UU no. 23 tahun 1999, UU no. 03 tahun 2004. Lembaga Penerbit Fakultas Ekonomi Universitas Indonesia.

View in (Google Scholar)

18. Handayani, S. (2009). Pengaruh Penyaluran Kredit dan Penyisihan Penghapusan Aktiva Produktif Terhadap Laba Operasional. Universitas Siliwangi Tasikmalaya.

View in (Google Scholar)

19. Wangi, Cendana G.L.A.L dan Ramantha, Wayan. Non Performan Loan Sebagai variable Pemoderasi Pengaruh KUR pada Profitabilitas PT. BR Vol. 2I (Persero) Tbk. Cabang Denpasar. E- Journal Universitas Udayana. Volume 2 No.1 Juli. 2017. ISSN 2302-8556

View in (PDF)

20. Wardhani, S., \& BASUKI, M. U. (2011). Analisis Pengaruh Spread Tingkat Suku Bunga Bank, CAR, dan NPL Terhadap Penyaluran Kredit UMKM Oleh Perbankan Di Indonesia(Doctoral dissertation, Universitas Diponegoro).

View in (Google Scholar)

21. Adetunji, A. T., Adetunji, A. V., Adeleke, E. O., \& Madubuike, S. C. (2017). Deregulation: The Effect of Market-led Approach to Nigerian Universities Management. International Journal of Social Sciences and Humanities (IJSSH), 1(1), 1-8.

View in (Google Scholar)

22. Dewi, I. G. A. A. O., \& Dewi, I. G. A. A. P. (2017). Corporate Social Responsibility, Green Banking, and Going Concern on Banking Company in Indonesia Stock Exchange. International Journal of Social Sciences and Humanities (IJSSH), 1(3), 118-134.

View in (Google Scholar)

23. Pemayun, A. G. P., \& Maheswari, A. I. A. (2017). Economic Impacts of Craftsman Statue on Community Based Tourism Development. International Journal of Social Sciences and Humanities (IJSSH), 1(3), 59-73. View in (Google Scholar)

24. Mora, M. M., Espinosa, M. R., \& Delgado, M. R. (2018). Approach of Processes for the Distribution of Economic Resources in Public University of Ecuador. International Research Journal of Management, IT and Social Sciences (IRJMIS), 5(1), 25-35.

View in (Google Scholar)

25. Hadi, A., Handajani, L., \& Putra, I. N. N. A. (2018). Financial Disclosure based on Web-ICT Determinants: Its Implications for Local Government Financial Performance in Indonesia. International Research Journal of Management, IT and Social Sciences (IRJMIS), 5(1), 72-85.

View in (Google Scholar) 
26. Louzis, D. P., Vouldis, A. T., \& Metaxas, V. L. (2012). Macroeconomic and bank-specific determinants of non-performing loans in Greece: A comparative study of mortgage, business and consumer loan portfolios. Journal of Banking \& Finance, 36(4), 1012-1027.

View in (Google Scholar)

27. Kauko, K. (2012). External deficits and non-performing loans in the recent financial crisis. Economics Letters, 115(2), 196-199.

View in (Google Scholar)

28. Ghosh, A. (2015). Banking-industry specific and regional economic determinants of non-performing loans: Evidence from US states. Journal of Financial Stability, 20, 93-104.

View in (Google Scholar)

29. Meeker, L. G., \& Gray, L. (1987). A note on non-performing loans as an indicator of asset quality. Journal of banking \& finance, 11(1), 161-168.

View in (Google Scholar)

30. Barseghyan, L. (2010). Non-performing loans, prospective bailouts, and Japan's slowdown. Journal of Monetary Economics, 57(7), 873-890.

View in (Google Scholar)

Biography of Author

\begin{tabular}{||l|l|}
\hline & Ketut Tanti Kustina, SE., MM., AK., CA. is an Assistant Professor of Accounting. \\
& Registration of civil servant: 19811116 200501 2 003. She works Undiknas \\
University. She graduated her Bachelor Degree in accounting in Udayana \\
University in 2004. She finished her Master Degree in financial management at \\
Udayana University in 2010. She teaches some subjects included corporate social \\
responsibility/ sustainability accounting, financial statement analysis, financial \\
management, good corporate governance, and contemporary financial accounting. \\
She had been authored some paper that published at the national level. She is also \\
active to follow seminars and workshop regarding her qualification. She is a \\
member of IAI (Indonesian Accountant Association), ISEI (Indonesian Economic \\
Scholar Association, and SPI in Kopertis Regional VIII (I Internal Control Unit).
\end{tabular}

Kustina, K., Dewi, I., Prena, G., \& Utari, I. (2018). MSMEs Credit Distribution and Non-Performing Loan towards Banking Companies Profit in Indonesia. International Journal Of Social Sciences And Humanities (IJSSH), 2(1), 10-23. doi:10.29332/ijssh.v2n1.72 